\title{
Factors Influencing an Organisations ability to Manage Innovation: a Structured Literature Review and Conceptual Model
}

* Marisa Smith, Research Assistant, Centre for Business Process Outsourcing, University of Strathclyde, James Weir Building, 75 Montrose Street, Glasgow, G1 1XJ, +44(0)141548 2588, m.k.smith@ strath.ac.uk

Marco Busi, CEO and Head of Research, Carisma RCT Ltd., Haliday House, Dingwall Business Park, IV15 9XL, Dingwall, +44 (0) 1349868 315, m.busi@carismarct.com

Peter Ball, Senior Lecturer, Department of Manufacturing, Building 50, Cranfield University, Cranfield, Bedford, MK43 0AL, +44 (0)1234 750111 ext 5657, p.d.ball@cranfield.ac.uk

Robert van der Meer, Senior Lecturer, Department of Management Science, University of Strathclyde, Graham Hills Building, 40 George Street, G1 1EQ, +44 (0)141 548 3515, robert.van-der-meer@strath.ac.uk 


\title{
Factors Influencing an Organisations ability to Manage Innovation: a Structured Literature Review and Conceptual Model
}

\begin{abstract}
Management literature prescribes innovation as a stimulus for sustained competitive advantage in companies however the nature of the development in this field has resulted in the literature being broad and fragmented. This paper focuses on the body of literature concerned with the factors which influence innovation management in organisations. The aim of this research is to present a holistic view of the factors that effect innovation management. Using a systematic literature review approach, using over 100 papers, this research identifies 9 key factors that impact on an organisations ability to manage innovation. These 9 factors have been identified as management style and leadership, resources, organisational structure, corporate strategy, technology, knowledge management, employees and innovation process. The paper then discusses the inductively derived model that presents the important relationships identified between the factors to present a holistic view of innovation management. From this we open up the debate on innovation management as a systemic approach rather than being focused on the singular factors. We can therefore conclude that a number of dominant relationships exist between the factors with the innovation process being the only endogenous factor within the model.
\end{abstract}




\section{Introduction}

Innovation has long been cited as essential for organisational competitiveness and success (McAdam and Keogh, 2004; Edwards et al., 2005). This awareness of innovation has generated a great deal of literature on the subject of innovation. As a result innovation has become an extensive concept that can be perceived in a number of different ways. For the purpose of this research we used Tidd et al's (2001: 38) definition of innovation which is "Innovation is a process of turning opportunity into new ideas and of putting these into widely used practice". Damanpour (2001) presents a typology of innovation types, innovation can be radical, incremental, product, process, administrative or technical. By drawing these two definitions together innovation in the context of this research work can be thought of at its broadest sense, considering various types of innovation.

A wide body of literature has arisen that identifies the common factors shared by innovative organisations and the factors that impact on the ability to manage innovation. The general management literature often prescribes that organisations should increase their organisational innovativeness to remain competitive (Porter, 1990; Lengnick-Hall, 1992; Roberts, 1998), but the literature often neglects to address how organisations can impact on their ability to manage innovation. Using this body of literature we conduct a structured literature review that identifies the organisational factors that influence the ability to manage innovation at the firm level. Such a systematic approach to the innovation literature is missing from the current body of literature. By identifying and analysing the factors, we identify where relationships between the factors exist, this is achieved though identification of the relationships that are commonly cited in the literature. This will enable academics and practitioners alike to understand what factors can be manipulated by organisations to increase their ability to manage innovation. Although this paper does not provide a prescriptive method for organisations to follow to become innovative, it does identify what factors and relationships are important in impacting an organisations ability to manage innovation.

The aim of this paper is to provide a comprehensive view of the factors which influence an organisations ability to manage innovation. Often studies regarding success factors for innovation considers these factors independent of each other (for example, van der Panne et al., 2003), we argue in this paper that the factors are not independent of each other and are in fact interrelated. We therefore put forward the proposition that innovation management needs to be considered in a holistic manner.

\section{Methodology}

The fundamental research problem that faces any researcher working in the area of innovation is the vastness of literature on the subject. The authors used a systematic literature review technique as an effective means of coping with the number of papers published in this area.

Although systematic review theory was developed from medical research methods, it is gaining awareness in the management research field (Tranfield et al., 2003; Denyer and Neely, 2004; Pittaway et al., 2004). Traditional narrative literature reviews are 
criticised for being heavily influenced by researcher bias (Mulrow, 1994; Denyer and Neely, 2004).

Systematic reviews "bring together as many studies as possible that are relevant to the research being undertaken, irrespective of their published location, or even disciplinary background" (Thorpe et al., 2004: 258). This must be done in a way that ensures that all the decisions that are made during the review process are transparent; this allows readers to determine the suitability of the studies included and the robustness of the conclusions drawn (Denyer and Neely, 2004).

The literature search begins with keywords and search terms (Tranfield et al., 2003). For this study, we selected the following keywords and strings: drivers AND innovati*, barriers AND innovati*, organisatio* AND innovati*, "factors influencing innovation", "innovative organisation", "innovativeness" and "organisational innovativeness". These keywords were entered into prominent academic databases, including ABI Proquest, Emerald and Ingenta. The databases were searched for citations from 1960 to present. This process resulted in the retrieval of 4,212 citations.

Using the same methodology as Thorpe et al. (2005) these citations were then downloaded into bibliographic software, where the titles were analysed against predefined inclusion and exclusion criteria. Although there are weaknesses with analysing only the titles of studies other authors have found this approach useful when dealing with a massive amount of citations (Pittaway et al., 2004; Thorpe et al., 2005). If there was ambiguity with a study's title, the citation abstract was reviewed to understand the relevance of the study. At this point, the citations were examined to identify duplicate citations, book reviews and anonymous authors. After this initial review and title analysis, 977 relevant citations remained in the database.

\section{Criteria to Select Sources}

The abstracts of the selected 977 citations were analysed to understand their fit and contribution to the purpose of this study. We defined a set of characteristics that a paper should present in order to maximise the quality of the systematic review, these inclusion criteria are seen in table 1.

\section{Table 1 - Inclusion Criteria}

\begin{tabular}{ll}
\hline Criteria & Reasons for Inclusion \\
\hline All industries and sectors & $\begin{array}{l}\text { To gain a wide picture of the factors that affect organisational } \\
\text { innovation and innovativeness - not just limited to one area. } \\
\text { To ensure a cross-cultural view of organisational innovativeness. }\end{array}$ \\
$\begin{array}{l}\text { All countries } \\
\text { Barriers to innovation in } \\
\text { organisations }\end{array}$ & $\begin{array}{l}\text { To identify the factors that inhibits innovation in the organisational } \\
\text { context. }\end{array}$ \\
$\begin{array}{l}\text { Drivers for innovation in } \\
\text { organisations }\end{array}$ & $\begin{array}{l}\text { To identify the factors that encourages innovation in the organisational } \\
\text { context. }\end{array}$ \\
Characteristics of innovative & To identify the characteristics that are evident in organisations that \\
organisations & have been recognised as innovative \\
\hline
\end{tabular}

Conducting a similar exercise, a set of exclusion criteria were identified (as seen in table 2) these identify the characteristics which would make a paper worthless to this study. 
Table 2 - Exclusion Criteria

\begin{tabular}{ll}
\hline Criteria & Reasons for Exclusion \\
\hline $\begin{array}{l}\text { National systems of } \\
\text { innovation }\end{array}$ & This is not in the organisational context. \\
$\begin{array}{l}\text { Implementation of specific } \\
\text { innovations }\end{array}$ & The results are focused on the innovation being implemented. \\
$\begin{array}{l}\text { Consumer innovativeness } \\
\text { To exclude many articles that focus on how consumer innovativeness } \\
\text { affects the product/services they buy. }\end{array}$ \\
\hline
\end{tabular}

As a result of this stage, 102 studies were considered pertinent to this literature review (marked bold in the references). The full texts of the studies were then reviewed indepth to extract organisational factors that impact the ability to manage innovation.

\section{Identifying the factors influencing an organisations ability to manage innovation}

The 102 studies selected were analysed to identify factors affecting organisations ability to manage innovation. From each article full text, the factors described were located in the text extracted as quotes into a database, e.g. "shared vision" from Calatone et al., (2002) and Garcia-Morales et al., (2006). This was repeated for the 102 articles resulting in 423 database entries. Any exact duplicate quotes (factors) were immediately eliminated, reducing the entries to 321. Additionally any factors that were concerned with common themes were merged, e.g. "Leadership" and "Leadership style" were combined. This reduced the number of factors to 295. However, many of the factors in the database were related to one another, e.g. "Market knowledge" and "Knowledge integration". To be of use to study innovation the factors needed further consolidation.

To rationalise the factors influencing an organisation's ability to manage innovation a strategy was used that has been described in different ways by different authors. Jones (2004) uses 'Nominal Group' technique, i.e. a physical gathering where the participants use brain-storming techniques, and private ranking of ideas and tabulation (Mays and Pope, 2000).

This was repeated across all the 295 original factors in the database to create 31 subfactors shown in column 2 of Table 3. The process did not group beyond the point where further interpretation of authors' descriptions of factors would have been required. The second stage used the factor groupings cited by Damanpour (1991); Read (2000); Lemon and Sahota (2004); Webster (2004) to establish clusters of the 31 sub-factors created. The clustering resulted in nine 'generic' factors being identified that could collectively represent all the original factors from the database, these are shown in column 1 of Table 3. To maintain traceability of these nine factors to the factors quoted from the full text articles the links to the 31 sub-factors and 295 original factors were maintained. For example under the factor "Technology" there are a number of sub-factors including "Utilisation of technology". For brevity, a third column in Table 3 that lists the links to the 295 original remaining factors has been omitted. 
Table 3 - Factors and sub-factors influencing an organisations ability to manage innovation

\begin{tabular}{|c|c|}
\hline Factor & Sub-Factors \\
\hline Technology & $\begin{array}{l}\text { Utilisation of technology } \\
\text { Technical skills and education } \\
\text { Technology strategy }\end{array}$ \\
\hline Innovation process & $\begin{array}{l}\text { Idea generation } \\
\text { Selection and evaluation Techniques } \\
\text { Implementation mechanism }\end{array}$ \\
\hline Corporate strategy & $\begin{array}{l}\text { Organisational strategy } \\
\text { Innovation strategy } \\
\text { Vision and goals of the organisation } \\
\text { Strategic decision making }\end{array}$ \\
\hline Organisational structure & $\begin{array}{l}\text { Organisational differentiation } \\
\text { Centralisation } \\
\text { Formality }\end{array}$ \\
\hline Organisational culture & $\begin{array}{l}\text { Communication } \\
\text { Collaboration } \\
\text { Attitude to risk } \\
\text { Attitude to innovation }\end{array}$ \\
\hline Employees & $\begin{array}{l}\text { Motivation to innovate } \\
\text { Employee skills and education } \\
\text { Employee personalities } \\
\text { Training }\end{array}$ \\
\hline Resources & $\begin{array}{l}\text { Utilisation of slack resources } \\
\text { Planning and management of resources } \\
\text { Knowledge resources } \\
\text { Technology resources } \\
\text { Financial resources }\end{array}$ \\
\hline Knowledge management & $\begin{array}{l}\text { Organisational learning } \\
\text { Knowledge of external environment } \\
\text { Utilisation of knowledge repositories }\end{array}$ \\
\hline Management style and leadership & $\begin{array}{l}\text { Management personalities } \\
\text { Management style } \\
\text { Motivation of employees }\end{array}$ \\
\hline
\end{tabular}

In pursuit of clarity we have described what each of the factors mean in the context of this research as they can often have different meanings in different contexts.

Technology. Technology is often discussed as an output of innovation (Erdener and Dunn, 1995; Madsen et al., 2005), but in this research we are concerned with its role as an influencing factor. Technology discussed in this paper is concerned with the utilisation of technology to facilitate innovation and innovative behaviour within and between organisations.

Innovation process. Although a few authors (Cummings and O'Connel, 1978; Knight, 1987; Amar, 2004; Galia and Legros, 2004; Bessant et al., 2005; Merx-Chermin and Hijhof, 2005) discuss the impact of operational processes on organisational 
innovativeness, in the context of this paper processes relate to the generation, development and implementation of innovations.

Corporate Strategy. Strategy is a wide subject area and the definition can often be confusing. Strategy in this research refers to aspects of the corporate and innovation strategies of the organisation (Damanpour and Evan, 1984; Read, 2000; Martins and Terblanche, 2003) and how they impact on the management of innovation. It also refers to the dissemination of the strategic vision throughout the organisation.

Organisational structure. Organisational structure has received much attention in the general management literature (e.g. Mintzberg, 1992) and often covers more than the simple configuration of the organisation. However, within this research organisational structure relates to the way the various parts of an organisation are configured and how this impacts on an organisations ability to manage innovation.

Organisational culture. Culture here refers to the culture of the organisation, although organisational culture has been discussed widely in general management literature (e.g. Hofstede, 2001). In the context of this research it relates to the values and beliefs of the organisation and how these impact the ability to manage innovation within the organisation. It takes into consideration the organisation's approach to collaboration, communication and risk.

Employees. Employees refers to the non-management employees of the organisation and the role they play in affecting innovation management. This factor takes into account the various personal characteristics associated with employees (e.g. Ahmed, 1998; Bharadwaj and Menon, 2000) and the motivation of employees to become innovative (e.g. Mostafa, 2005).

Resources. Relates to all the resources that the organisation has, human, financial and physical, but they are discussed in relation to the level of slack resources (e.g. Nohria and Gulati, 1996; Subramanian and Nilakanta, 1996) and how resources are managed (e.g. Knight, 1987; Wan et al., 2005) to impact on an organisations ability to manage innovation.

Knowledge management. Knowledge management in this research refers to the management and utilisation of knowledge for innovation management. This covers all aspects of knowledge, both internal and external to the organisation. This factor will also take organisational learning into consideration as it plays a key role in knowledge management (e.g. Salavou, 2004; Ng, 2004).

Management style and leadership. Management style and leadership refers to the employees that have responsibility for the management of the organisation. This factor is concerned with a number of aspects to the way management influences the management of innovation. For example it takes into account the management style within the organisation (e.g. Pearson et al., 1989; Hyland and Beckett, 2005) and how management can motivate employees to become more innovative (e.g. Roffe, 1999; Rivas and Gobeli, 2005). 
Table 3 synthesises the results and discussions of a large number of papers and puts them into a common framework. The results of this stage of the research show that there are 9 factors (and relating sub-factors) that influence an organisations ability to manage innovation. Many authors have already performed this type of analysis of the literature (Damanpour, 1991; Tidd et al., 2001; Bessant, 2003) but it has been limited in its scope.

Although our findings do share some common factors with other studies we have provided a more comprehensive view of the literature concerning the factors that influence innovation management. The work carried out in this research encompasses different academic fields and organisational contexts and has drawn together the findings from over 100 studies on innovation to develop the factors in table 3 .

The value in this work is not in the identification of the factors but the examination of the important relationships between the factors. This provides a more complete view of how these factors and relationships impact on innovation management. This research aims to open up the debate on innovation management as a systemic approach by organisations and not merely focused on singular factors.

\section{Relationship Model of Factors Influencing the Management of Innovation}

\section{Development of Model}

Through the structured review process a number of relationships which exist between the factors was captured. From this literature review we can identify the commonly cited relationships that exist between the factors identified, this is shown in Figure 1. The relationships (and direction of the relationships) between the factors are denoted in the model by the arrows. The arrows, and therefore relationships, were identified after the factors (as seen in table 3 ) had been inductively derived. Further review of the 102 papers examined reference to relationships between any of the factors. While the literature shows that all the factors had some level of relationship between them there were some relationships that were more commonly discussed then others, it is these commonly discussed relationships we have synthesised into an inductive model in this paper.

It is important to note at this point that organisational culture will require special attention in the paper as it is the most commonly cited factor in the literature for impact an organisations ability to manage innovation. It was also seen to have the widest impact on the other factors, organisational culture is pervasive therefore we see no benefit in explicitly linking it to the other factors in the model. 


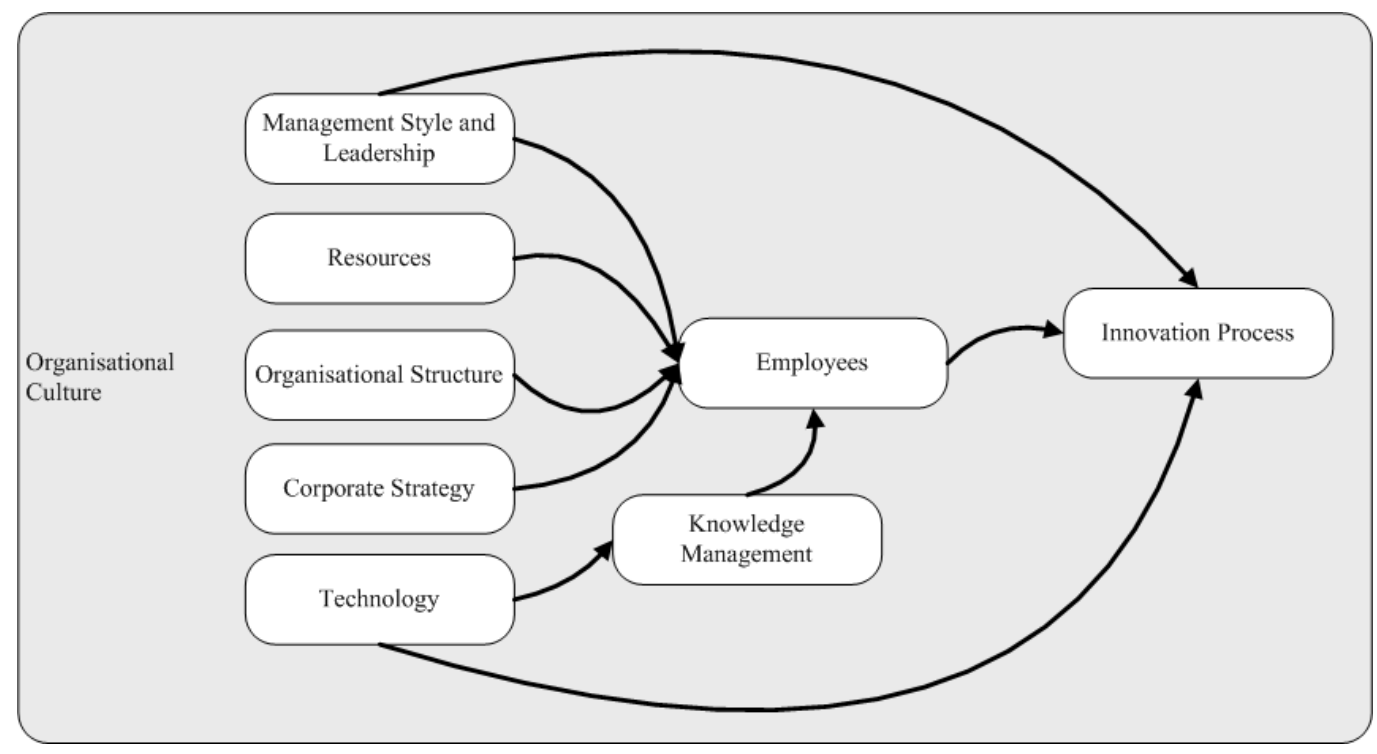

Figure 1. Relationships between the factors

\section{Role of organisational culture}

For this research 'culture' relates to the values and beliefs of the organisation and how these impact the management of innovation within the organisation. It takes into consideration the organisation's approach to collaboration, communication and risk. Organisational culture is often intrinsic to the way an organisation functions and the values it engenders within its operation. It is also the most commonly discussed factor relating to an organisations ability to manage innovation identified within this study. Ahmed (1998) goes as far to say that it is the 'primary determinant' of innovation. Due to the pervasive role that organisational culture plays in the management of innovation this factor is discussed separately.

The relationship between culture and strategy is highly complex and it is often difficult to separate the effects strategy and culture have on each other. The relationship between these two factors is examined within the literature in two ways. Firstly, in the way the culture will drive the strategy adopted, for example some authors (Veugelers and Cassiman, 1999; Craven et al., 2002) discuss the impact having a culture that encourages risk will have on developing strategies that have higher levels of risk. Secondly, the literature discusses the impact corporate strategy has on organisational culture. For example, some authors argue that by having a shared vision of innovation, the organisations strategic goals will translate into the organisation's culture (Vrakking, 1990; Calantone et al., 2002; Martins and Terblanche, 2003; Lemon and Sahota, 2004; Ng, 2004 Garcia-Morales et al., 2006). Therefore it can be seen that an organisation's strategy can represent the underlying culture that currently exists but corporate strategy can also drive the culture within the organisation. There is a delicate relationship between these two factors and strategic change often requires a substantial change in organisational culture (Balogun et al., 2004).

It is often difficult to separate organisational culture and organisational structure as both have developed in parallel over the lifetime of the organisation. While the literature is in agreement on the nature of organisational culture for managing 
innovation it is more difficult to discuss the organisational structure conducive to effective management of innovation. Mintzberg (1979) describes the 'innovative organisation' in his seminal work but this is a simplistic view of organisational structure for innovation management. Burns and Stalker (1961) on the other hand provide a contingent approach that highlights the complexities of organisational context on the management of innovation, it is this approach that we adopt when considering the relationships within our model.

Management style, techniques and behaviour often reflect the culture of the organisation. A move away from an autocratic management style to a more participatory and democratic style of management reflects a culture that is focused on stimulating innovation (Pearson et al., 1989; Roffe, 1999; Rivas and Gobeli, 2005; Hyland and Beckett, 2005). Some authors maintain that a change in management attitude and approach can actually engender a culture that encourages and supports innovation (McDonough and Leifer, 1986; Knight, 1987; Pearson et al., 1989; Damanpour, 1991; Roffe, 1999; Read, 2000; Zwetsloot, 2001; Jaskyte, 2004; Hyland and Beckett, 2005; Mostafa, 2005; Rivas and Gobeli, 2005). Changes in management characteristics can impact on the ability of organisations to manage innovation but McDonough and Leifer's (1986) view that management must retain a balance between an innovative culture and the maintenance of everyday operational requirements is also important. This balanced view is often missing from the wider innovation literature.

The notion of extended and networked enterprises has long been discussed in the general management field, and a culture that supports collaboration means that networking can become a reality. Networking with other organisations, whether longterm or short-term, can result in an organisation's attitude to innovation changing (Hadjimanolis, 2000; Kandampully, 2002; Pavitt, 2002; Flor and Oltra, 2004; Jaskyte and de Riobo, 2004; Medina et al., 2005; Mudrak et al., 2005). This is because the organisation becomes open to new ways of thinking and doing, and learns from the experiences of other organisations or external bodies. One of the key ways that organisations can increase their external linkages is through their employees having contact with external bodies such as universities and professional institutions. This interaction with the external environment often results in increased levels of professionalism in the organisational culture. Professionalism is often discussed in relation to the positive impact it has on an organisation's ability to manage innovation (Daft, 1978; Damanpour, 1987).

The willingness to learn and generate knowledge is something that needs to be inherent in the organisation's culture (Subramanian and Youndt, 2005). An organisational culture that actively seeks out new knowledge and learning opportunities has a culture that is descried as a 'learning orientation' (Glynn, 1996; Bharadwaj and Menon, 2000; Calantone et al., 2002; Chanal, 2004; Hult et al., 2004; Salavou, 2004; Bates and Khasawneh, 2005; Brennan and Dooley, 2005; MerxChermin and Hijhof, 2005). This learning orientation is a culture that supports the generation of knowledge through a variety of channels, such as learning from past projects or obtaining knowledge external to the organisation. Learning here suggests that the organisation also utilises the knowledge that has been gained through the learning process. Organisations that have a high level of learning orientation and knowledge generation use the knowledge to generate and develop new ideas. 
Accordingly, the more often organisations exploit their knowledge resources then the greater chance they have of increasing the number of innovations they develop (Pavitt, 2002). Organisations that learn from their mistakes have a different type of culture from those organisations that relinquish when they make a mistake.

Although in this section we have identified some of the direct relationships culture has with the other factors, it also has residual effects on other factors within the model. These effects will be discussed further in the analysis of the model.

\section{Analysis of Model}

As we have discussed, organisational culture permeates all of the factors in the model and it is inappropriate to separate culture from each of the factors. The culture that engenders innovation is often described as open, where creativity and risk taking are encouraged and information freely flows around the organisation (Roffe, 1999; Calatone et al., 2002; Wan et al, 2005). The shared vision of an organisation that supports and encourages idea generation and development needs to be put in place before other changes can be made to the organisational factors.

Management style and leadership, Resources, Employees and Innovation process. The literature supports the view that employees that are empowered and autonomous have a greater degree of control over their work. This degree of control means that employees feel comfortable in their role to be innovative in their own work environment (Thamhain, 1990; Tang, 1999; Zwetsloot, 2001; Amar, 2004; Mostafa, 2005; Muthusamy et al., 2005; Nystrom et al., 2002). However, some authors argue that the level of management support given to empowered employees will affect their ability to innovate (Knight, 1987; Tang, 1999; Martins and Terblanche, 2003; Mostafa, 2005); therefore employees must not feel alone in the pursuit of innovation. Although employees are fundamental to the generation and development of new ideas the literature argues that employees need to be given sufficient resources, in time, materials and finance to allow ideas to emerge (Thamhain, 1990; Avlonitis et al., 1994; Pavitt, 2002; Hyland and Beckett, 2005; Mostafa, 2005). It is therefore the role of management to ensure that the innovation process comes to fruition and that employees know how to interact with the innovation process (Vandermerwe, 1987; Johnson, 1990).

Organisational structure and Employees. Organisational structure directly influences employees within the organisation and this is done through a number of channels such as the way teams are organised and the degree of formality. The organisational structure can often dictate the nature of the jobs in the organisation (Meadows, 1980; Koberg et al., 1996; Hage, 1999; Lewis and Moultrie, 2005). While lone employees can develop innovations, teams of employees will be more important in influencing overall ability of the organisation to innovate (Anderson and West, 1998; Read, 2000; Lemon and Sahota, 2004; Noke and Radnor, 2004; Muthusamy et al., 2005). The use of team-based working is dependant on other factors such as open and collaborative organisational culture and participatory management style therefore employees working in teams will be more open to discuss and implement new ideas within their teams.

Corporate strategy and Employees. The corporate strategy needs to be developed to reflect the organisational culture and communicate the shared vision and goals of the 
organisation (Cottam et al., 2001; Ng, 2004; Jager et al., 2004). All employees of the organisation need to understand how the corporate strategy impacts upon their jobs and what they need to do to help the organisation achieve their goals (Pearson et al., 1989). Therefore, if an organisation wants to be more effective at developing innovations this needs to be reflected somewhere within the corporate strategy, otherwise employees will not see how innovation directly impacts on their day-to-day tasks.

Technology, Knowledge management and Employees. Technology indirectly impacts employees through knowledge management this is because ICT is commonly used as a facilitator of knowledge transfer (Sorensen and Stuart, 2000; Kandampully, 2002); drawing together fragmented knowledge resources to develop a single knowledge repository (Ettlie, 1980; Damanpour, 1987; Jantunen, 2005). This means that employees can gain access to a wide based of knowledge that is collected throughout and beyond the organisation, and having this information readily available can support employees in the development of new ideas. Successfully using knowledge and learning tools, such as a knowledge repository, to feed into the innovation process results in an integrated approach to new idea development and implementation (Neely et al., 2001; Aranda and Molina-Fernandez, 2002).

Technology and Innovation process. The innovation process is the only endogenous factor within the model, meaning that is derived internally by other factors within the model. It is affected by the employees, the management style and leadership of the organisation and the technology used to enable the management of the process. Technology is often used in a supportive role to alleviate various stages of the innovation process (Watts et al., 1998; Petroni, 1998; Loewe and Dominiquini, 2006). More often than not technology is discussed in relation to the 'fuzzy' front end of the innovation process. This is the stage of the innovation process where ideas are generated and that is difficult to capture and explain, hence the use of technology to facilitate useful idea generation. Technologies such as virtual reality (Watts et al., 1998) and group work software (Klein and Dologite, 2000; Pissarra and Jesuino, 2005) all have a place in the innovation process.

Employees and Innovation process. Our model identifies employees as the conduit between the organisational factors and the innovation process. They play a central role in developing ideas as inputs into the innovation process and without ideas the innovation process simply would not function. The literature highlights that the employees of the organisation are a potential rich source of ideas and they should be encouraged to take part in the early stages to ensure a constant supply of ideas is generated to input into the innovation process (Woodman et al., 1993; Guimaraes and Langley, 1994; Andriopoulos and Lowe, 2000; McAdam and McClelland, 2002; Thamhain, 2003; Wood, 2003). Some authors do stress that employees need to be trained and educated before they can have a positive impact on the innovation process (Koen and Kohli, 1998; Loewe and Dominiquini, 2003; Pohlmann et al., 2005; Brennan and Dooley, 2005; Shipton et al., 2006).

In this section we have identified each of the commonly cited relationships and have examined the nature of the relationships that exist between the factors. The analysis of the model has highlighted that the relationships between the factors are complex and it can be difficult to tease out the main relationships existing between the factors. 
However, we have presented a view of the factors absent from the innovation management literature.

\section{Discussion}

Frequently innovation management literature discusses the factors that affect organisations' ability to innovate in a way that treats the factors as mutually exclusive, meaning that each factor has an individual impact on innovation. However the relationships between the factors and the impact these relationships have on innovation are largely ignored. This means that the cumulative effect of the factors and their relationships are not fully understood. This paper has shown that there are a number of important relationships that need to be examined in greater detail to understand how their effects impact on an organisation's ability to manage innovation.

Figure 1 shows that the innovation process is the factor that is impacted in some way by all other factors which can be deemed as the pinnacle factor that needs to be in place for organisations to successfully manage innovation. Looking at the model in figure 1 it can be seen that a number of the factors are exogenous which means they are not impacted by other factors within the model, these factors group together to impact on knowledge management, employees and the innovation process. Therefore, we have condensed this collection of factors into one group. This leads to the model being considered in a more simplistic way, taking the structure of a pyramid, figure 2 highlights how the model can be restructured.

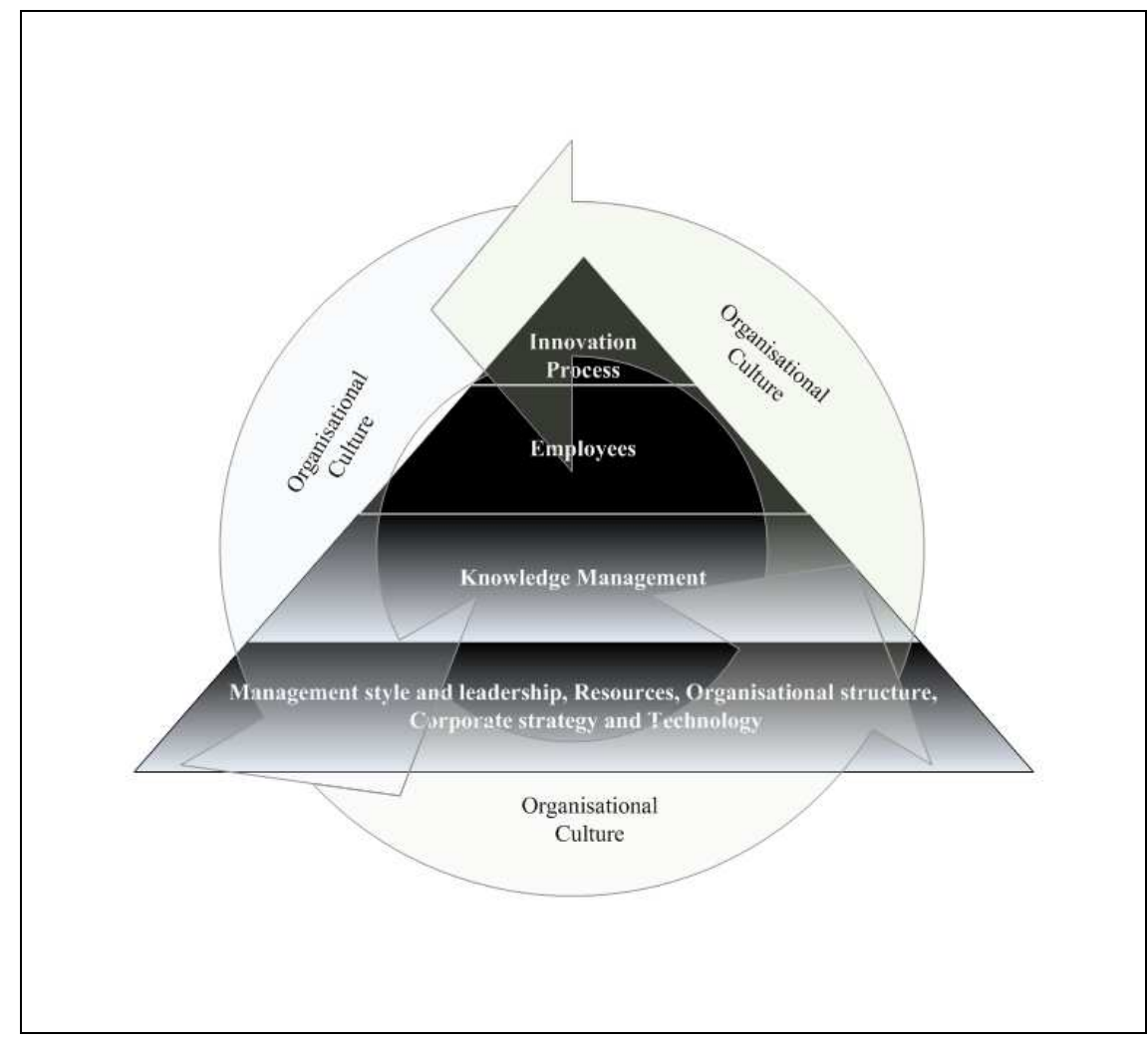

Figure 2. Factors of innovation pyramid 
The exogenous factors, that have been grouped together, form the base of the pyramid. This shows that they are the foundation factors that define an organisation, such as the organisational structure and corporate strategy. Knowledge management and employees are the conduit between the organisation and the innovation process. It is the employees of the organisation that 'feed' the innovation process with ideas. The innovation process is placed at the top of the pyramid as this is the only endogenous factor within the model in figure 1. The role of organisational culture is one that is continuously developing and evolving. As changes are made in the levels of the pyramid the organisational culture also changes and provides a virtuous (or vicious) circle of culture that engenders (or inhibits) innovation.

This paper has looked at the factors that influence innovation in a different way. We have endeavoured to understand the complex relationships that exist between the factors affecting innovation management to allow for a more complex view of innovation in the organisational context. By adopting a holistic view we can see that changing the nature of some factors can impact on other factors which might have a positive effect on the way innovation in managed in companies.

The key emerging issues identified in this paper are that some factors that impact innovation are more important than others. This paper has also drawn attention to the need to understand the effects the inter-factor relationships have on an organisations ability to manage innovation. There is little empirical evidence on the way relationships affect innovation, it could be that two or more factors being used together in an coherent way is more effective in stimulating innovation that the factors are on their own. It is this systems view that is missing from current thinking on innovation management in organisations.

\section{Conclusions}

The research presented in this paper draws three main conclusions. Firstly, there are 9 important factors that impact on an organisation's ability to manage innovation, namely; management style and leadership, resources, organisational structure, technology, knowledge management, corporate strategy, employees, and the innovation process.

Secondly, organisational culture is a key factor in the management of innovation. It is a factor that impacts all others and is also impacted upon by changes in the other factors. Therefore we can conclude that organisational culture emerges and develops through changes in the other factors.

Thirdly, the common relationships that exist among these 9 factors and how can impact on the management of innovation have been identified. By examining these relationships it can be seen that there are a number of exogenous factors that are not impacted by any other factors within the model. These exogenous factors are technology, organisational structure, resources and management style and leadership. This means that these factors play an important role in the antecedent phase of effective innovation management. The innovation process is the only endogenous factor within the model which means that it does not impact on any other factor within the model although it is influenced by other factors within the model. This means that the innovation process is a key factor to which all other factors impact which suggests 
that the other factors impact an organisations ability to manage innovation through the mediating effect of the innovation process.

\section{Practical Implications}

The managerial implications of this work are twofold. Firstly, organisations can understand how the 9 factors influence their ability to mange innovation and can consider the nature of the factors currently within their organisations. Secondly, organisations can understand that these factors do not operate independent of each other but are interrelated. They can use the model as a thinking tool to begin to understand that leveraging one factor will impact on a range of other factors.

Figure 2 provides organisations with a graphical representation of the findings of this study. This can be used to develop an understanding of how the factors piece together within their own organisational context.

The practical implication this research provides to scholars is that it provides a conceptual framework to build further research on. As the model presented in this paper is inductively developed from literature it therefore needs to be tested in subsequent empirical studies in order to test its validity and relevance. The model can be used to develop a series of hypothesises which can be tested within organisations to understand if the relationships identified from literature actually exist within the organisational context.

\section{Limitations and Further Research}

The literature on innovation is diverse and complex, and covers many different subject areas and research fields. This can make it difficult for academics and practitioners alike to understand the wide-ranging organisational factors that can influence an organisation's ability to become more innovative. There is agreement in the literature that due to the complexities associated with innovation research, we will never generate one true theory or best practice of innovation (Tidd, 2001). What is apparent is that the theories discussed hold true in various circumstances, such as; relating to life-cycle stage of the organisation (Koberg et al., 1996; Sorensen and Stuart, 2000), to the stage of development of the innovation (Gopalakrishnan and Damanpour, 1994), the type of innovation pursued (Damanpour, 1987; Damanpour et al., 1989) and the wider environment that the organisation operates within (Koberg et al., 1996; Brennan and Dooley, 2005). This contingency approach for generating theory is common in innovation research (e.g. Wolfe, 1994; Damanpour, 1996), but what is also important is the role of the relationships between the factors which influence an organisations ability to manage innovation. The relationships between factors will be influenced by organisational context such as organisational size, age and the external environment which are contingent factors. Although this paper has not examined the influence the contingency factors have on the relationships, we acknowledge that these factors are important to future research. Further work needs to be undertaken to understand how contingency factors will alter the relationships discussed in this paper, by contextualising any future empirical work based on a contingent approach. 


\section{References}

The references are highlighted in bold come from the systematic literature review process and have been directly used for the development the relationship diagram in figure 1 .

Adams, R., Bessant, J., and Phelps, R. (2006). Innovation management measurement: A review. International Journal of Management Reviews, 8(1), 21-47.

Ahmed, P. K. (1998). Culture and climate for innovation. European Journal of Innovation Management, 1, 30-43.

Amar, A. D. (2004). Motivating knowledge workers to innovate: A model integrating motivation dynamics and antecedents. European Journal of Innovation Management, 7(2), 89-101.

Anderson, N. R., \& West, M. A. (1998). Measuring climate for work group innovation: Development and validation of the team climate inventory. Journal of Organizational Behaviour, 19(3), 235-258.

Andriopoulos, C., \& Lowe, A. (2000). Enhancing organisational creativity: The process of perpetual challenging. Management Decision, 38, 734-742.

Aranda, D. A., and Molina, L. M. (2002). Determinants of innovation through a knowledge-based theory lens. Industrial Management \& Data Systems, 102, 289-298.

Avlonitis, G. J., Kouremenos, A., \& Tzokas, N. (1994). Assessing the innovativeness of organizations and its antecedents: Project Innovstrat. European Journal of Marketing, 28, 5-19.

Bates, R., \& Khasawneh, S. (2005). Organizational learning culture, learning transfer climate and perceived innovation in Jordanian organizations. International Journal of Training \& Development, 9(2), 96-103.

Bessant, J., Lamming, R., Noke, H., and Phillips, W. (2005). Managing innovation beyond the steady state. Technovation, 25, 1366-1376.

Bharadwaj, S., \& Menon, A. (2000). Making innovation happen in organizations: Individual creativity mechanisms, organizational creativity mechanisms or both? Journal of Product Innovation Management, 17, 424-437.

Boer, H., Caffyn, S., Corso, M., Coughlan, P., Gieskes, J., Magnusson, M, Pavesi, S. and Ronchi, S. (2001). Knowledge and continuous innovation: The CIMA methodology. International Journal of Operations and Production Management, 21(4), 490-504.

Brennan, A., \& Dooley, L. (2005). Networked creativity: A structured management framework for stimulating innovation. Technovation, 25(12), 1388-1399.

Brennen, M. Y. (1991). Culture as the critical factor in implementing innovation. Business Horizons, 34(6), 59-71.

Burns, T., and Stalker, G. M. (1961). The management of innovation. London: Tavistock.

Calantone, R. J., Cavusgil, S. T., \& Zhao, Y. (2002). Learning orientation, firm innovation capability, and firm performance. Industrial Marketing Management, 31(6), 515-527.

Chanal, V. (2004). Innovation management and organisational learning: A discursive approach. European Journal of Innovation Management, 7(1), 56-64. 
Chang, Y. C. (2003). Benefits of co-operation on innovation performance: Evidence from integrated circuits and biotechnology firms in the UK and Taiwan. $R \& D$ Management, 33(4), 425-439.

Cottam, A., Ensor, J., \& Band, C. (2001). A benchmark study of strategic commitment to innovation. European Journal of Innovation Management, $4(2), 88$ - 94.

Cravens, D. W., Piercy, N. F., \& Low, G. S. (2002). The innovation challenges of proactive cannibalisation and discontinuous technology. European Business Review, 14(4), 257-269.

Cummings, L. L., \& O'Connell, M. J. (1978). Organizational innovation: A model and needed research. Journal of Business Research, 6(1), 33-42.

Czarnitzki, D., \& Spielkamp, A. (2003). Business services in Germany: Bridges for innovation. The Service Industries Journal, 23(2), 1-12.

Daft, R. L. (1978). A dual-core model of organisational innovation. Academy of Management Journal, 21, 193-210.

Damanpour, F. (1987). The adoption of technological, administrative and ancillary innovation: Impact of organisational factors. Journal of Management, 13, 675-688.

Damanpour, F. (1991). Organisational innovation: A meta-analysis of effects of determinants and moderators. Academy of Management Journal, 34(3), 555-590.

Damanpour, F. (1996). Organizational complexity and innovation: Developing and testing multiple contingency models. Management Science, 42(5), 693-716.

Damanpour, F., \& Evan, W. M. (1984). Organizational innovation and performance: The problem of "organizational lag". Administrative Science Quarterly, 29(3), 392-408.

Damanpour, F., Szabat, K., and Evan, W. (1989). The relationship between types of innovation and organisational performance. Journal of Management Studies, 26(6), 587-601.

Davison, G., \& Blackman, D. (2005). The role of mental models in innovative teams. European Journal of Innovation Management, 8(4), 409 - 423.

Denyer, D., and Neely, A. (2004). Introduction to special issue: Innovation and productivity performance in the UK. International Journal of Management Reviews, 5-6(3-4), 131-135.

Dutta, S., \& Weiss, A. M. (1997). The relationship between a firm's level of technological innovativeness and its pattern of partnership agreements. Management Science, 43(3), 343-356.

Edwards, T., Battisti, G., McClendon Jnr., W. P., Denyer, D., and Neely, A. (2005). Pathways to value how UK firms create more value using innovation strategically: AIM Research.

Ettlie, J. E. (1980). Manpower flows and the innovation process. Management Science, 26(11), 1086-1097.

Flor, M. L., and Oltra, M. J. (2004). Identification of innovating firms through technological innovation indicators: An application to the Spanish ceramic tile industry. Research Policy, 33(2), 323-336.

García-Morales, V. J., Llorens-Montes, F. J., \& Verdú-Jover, A. J. (2006). Antecedents and consequences of organizational innovation and organizational learning in entrepreneurship. Industrial Management + Data Systems, 106(1/2), 21-32. 
Gloet, M., and Terziovski, M. (2004). Exploring the relationship between knowledge management practices and innovation performance. Journal of Manufacturing Technology Management, 15(5), 402-409.

Glynn, M. A. (1996). Innovation genius: A framework for relating individual and organizational intelligences to innovation. Academy of Management Review, 21(4), 1081-1111.

Goffin, K., and Mitchell, R. (2005). Innovation management: Strategy and implementation using the pentathlon framework. Basingstoke: Palgrave Macmillian.

Gopalakrishnan, S., \& Damanpour, F. (1994). Patterns of generation and adoption of innovation in organizations: Contingency models of innovation attributes. Journal of Engineering and Technology Management, 11(2), 95-117.

Guimaraes, T., \& Langley, K. (1994). Developing innovation benchmarks: An empirical study. Benchmarking: An International Journal, 1(3), 3 - 20.

Hadjimanolis, A. (2000). An investigation of innovation antecedents in small firms in the context of a small developing country. $R \& \# 38 ; D$ Management, 30, 235-246.

Hage, J. T. (1999). Organizational innovation and organizational change. Annual Review of Sociology, 25, 597-621.

Hoeve, A., \& Nieuwenhuis, L. F. M. (2006). Learning routines in innovation processes. Journal of Workplace Learning, 18(3), 171 - 185.

Hult, G. T. M., Robert, F. H., \& Gary, A. K. (2004). Innovativeness: Its antecedents and impact on business performance. Industrial Marketing Management, 33(5), 429-436.

Hurley, R. F. (1995). Group culture and its effect on innovative productivity. Journal of Engineering and Technology Management, 12(1,2), 57-76.

Hyland, P., and Beckett, R. (2005). Engendering an innovative culture and maintaining operational balance. Journal of Small Business and Enterprise Development, 12(3), 336-352.

Jager, B., Minnie, C., Jager, J., \& Welgemoed, M. (2004). Enabling continuous improvement: A case study of implementation. Journal of Manufacturing Technology Management, 15(4), 315-331.

Jantunen, A. (2005). Knowledge-processing capabilities and innovative performance: An empirical study. European Journal of Innovation Management, 8(3), 336 - 349.

Jaskyte, K. (2004a). Transformational leadership, organizational culture, and innovativeness in nonprofit organizations. Nonprofit Management and Leadership, 15(2), 153-163.

Jaskyte, K., and de Riobo, M. S. (2004b). Characteristics of innovative nonprofit organisations in Argentina. Voluntas: International Journal of Voluntary and Nonprofit Organisations, 15(1), 71-83.

Johannessen, J.-A., Olsen, B., \& Olaisen, J. (1999). Aspects of innovation theory based on knowledge-management. International Journal of Information Management, 19(2), 121-132.

Johnson, J. D. (1990). Effects of communicative factors on participation in innovation. The Journal of Business Communication, 27(1), 7-15.

Kandampully, J. (2002). Innovation as the core competency of a service organisation: The role of technology, knowledge and networks. European Journal of Innovation Management, 5(1), 18-26. 
Kirton, M. J. (1984). Adaptors and innovators - why new initiatives get blocked. Long Range Planning, 17(2), 137-144.

Kivimaki, M., Lansisalmi, H., Elovainio, M., \& Heikkila, A. (2000). Communication as a determinant of organizational innovation. $R \& D$ Management, 30(1), 33-42.

Klein, E. E., \& Dologite, D. G. (2000). The role of computer support tools and gender composition in innovative information system idea generation by small groups. Computers in Human Behaviour, 16, 111-139.

Knight, R. M. (1987). Corporate innovation and entrepreneurship: A Canadian study. The Journal of Product Innovation Management, 4(4), 284-298.

Koberg, C. S., Uhlenbruck, N., \& Sarason, Y. (1996). Facilitators of organizational innovation: The role of life-cycle stage. Journal of Business Venturing, 11, 133-145.

Koen, P. A., \& Kohli, P. (1998). Idea generation: Who has the most profitable ideas. Engineering Management Journal, 10(4), 35-43.

Laursen, K., \& Salter, A. (2004). Searching high and low: What types of firms use universities as a source of innovation? Research Policy, 33(8), 12011219.

Lemon, M., and Sahota, P. S. (2004). Organisational culture as a knowledge repository for increased innovative capacity. Technovation, 24, 483-498.

Lengnick-Hall, C. A. (1992). Innovation and competitive advantage: What we know and what. Journal of management, 18(2), 399-429.

Lewis, M., \& Moultrie, J. (2005). The organizational innovation laboratory. Creativity and Innovation Management, 14(1), 73-86.

Loewe, P., and Dominiquini, J. (2006). Overcoming the barriers to effective innovation. Strategy and Leadership, 34(1), 24-31.

Martins, E. C., and Terblanche, F. (2003). Building organisational culture that stimulates creativity and innovation. European Journal of Innovation Management, 6(1), 64-74.

Mavondo, F. T., Chimhanzi, J., \& Stewart, J. (2005). Learning orientation and market orientation: Relationship with innovation, human resource practices and performance. European Journal of Marketing, 39(11/12), 1235 - 1263.

Mays, N., and Pope, C. (2000). Assessing quality in qualitative research. British Medical Journal, 320(1 January), 50-52.

McAdam, R., and Keogh, W. (2004). Transitioning towards creativity and innovation measurement in SMEs. Creativity and Innovation Management, 13(2), 126139.

McAdam, R., \& McClelland, J. (2002). Individual and team-based idea generation within innovation management: Organisational and research agendas. European Journal of Innovation Management, 5(2), 86 - 97.

McDonough, E. F., III, \& Leifer, R. P. (1986). Effective control of new product projects: The interaction of organization culture and project leadership. The Journal of Product Innovation Management, 3(3), 149-158.

Meadows, I. S. G. (1980). Organic structure and innovation in small work groups. Human Relations, 33(6), 369-375.

Medina, C. C., Lavado, A. C., and Cabrera, R. V. (2005). Characteristics of innovative companies: A case study of companies in different sectors. Creativity and Innovation Management, 14(3), 272-287. 
Merx-Chermin, M., and Hijhof, W. (2005). Factors influencing knowledge creation and innovation in an organisation. Journal of European Industrial Training, 29(2), 135-147.

Miles, W. E., Miles, G., \& Snow, C. C. (2006). Collaborative entrepreneurship: A business model for continuous innovation. Organizational Dynamics, 35(1), 1-23.

Mintzberg, H. (1992). The structuring of organizations. In H. Mintzberg, and Quinn, J. B. (Ed.), The strategy process: Concepts and contexts. New Jersey: Prentice-Hall.

Mostafa, M. (2005). Factors affecting organisational creativity and innovativeness in Egyptian business organisations: An empirical investigation. The Journal of Management Development, 24(1/2), 7-33.

Mudrak, T., van Wagenberg, A., and Wubben, E. (2005). Innovation process and innovativeness of facility management organizations. Facilities, 23(3/4), 103-118.

Mulrow, C. D. (1994). Systematic reviews: Rationale for systematic reviews. British Medical Journal, 309(3 September), 597-599.

Muthusamy, S. K., Wheeler, J. V., \& Simmons, B. L. (2005). Self-managing work teams: Enhancing organizational innovativeness. Organization Development Journal, 23(3), 53-67.

Neely, A., Filippini, R., Forza, C., Vinelli, A., \& Hii, J. (2001). A framework for analysing business performance, firm innovation and related contextual factors: Perceptions of managers and policy makers in two European regions. Integrated Manufacturing Systems, 12(2), 114-129.

Nohria, N., and Gulati, R. (1996). Is slack good or bad for innovation? Academy of Management Journal, 39(5), 1245-1264.

Noke, H., \& Radnor, Z. J. (2004). Navigating innovation: A diagnostic tool supporting the process. Journal of Manufacturing Technology Management, 15(2), 172 - 183.

Nystrom, P. C., Ramamurthy, K., \& Wilson, A. L. (2002). Organizational context, climate and innovativeness: Adoption of imaging technology. Journal of Engineering and Technology Management, 19, 221-247.

Pak Tee, N. (2004). The learning organisation and the innovative organisation. Human Systems Management, 23(2), 93-101.

Pavitt, K. (2002). Innovating routines in the business firm: What corporate tasks should they be. Industrial and Corporate Change, 11(1), 117-133.

Pearson, G. J., Pearson, A. W., \& Ball, D. F. (1989). Innovation in a mature industry: A case study of warp knitting in the U.K. Technovation, 9(8), 657-678.

Petroni, A. (1998). The analysis of dynamic capabilities in a competence-oriented organization. Technovation, 18(3), 179-195.

Pissarra, J., \& Jesuino, J. C. (2005). Idea generation through computer-mediated communication: The effects of anonymity. Journal of Managerial Psychology, 20, 275-291.

Pittaway, L., Robertson, M., Munir, K., Denyer, D., \& Neely, A. (2004). Networking and innovation: A systematic review of the evidence. International Journal of Management Reviews, 5-6(3-4), 137-168.

Pohlmann, M., Gebhardt, C., \& Etzkowitz, H. (2005). The development of innovation systems and the art of innovation management - strategy, 
control and the culture of innovation. Technology Analysis \& Strategic Management, 17(1), 1-12.

Porter, M. E. (1990). The competitive advantages of nation. London, UK: Macmillian Press.

Read, A. (2000). Determinants of successful organisational innovation: A review of current research. Journal of Management Practice, 3(1), 95-119.

Rivas, R., \& Gobeli, D. H. (2005). Accelerating innovation at Hewlett-Packard. Research Technology Management, 48(1), 32-39.

Roberts, R. (1998). Managing innovation: The pursuit of competitive advantage and the design of innovation intense environments. Research Policy, 27, 159-175.

Roffe, I. (1999). Innovation and creativity in organisations: A review of the implications for training and development. Journal of European Industrial Training, 23, 224-241.

Salavou, H. (2004). The concept of innovativeness: Should we need to focus? European Journal of Innovation Management, 7(1), 33-42.

Salavou, H., Baltas, G., \& Lioukas, S. (2004). Organisational innovation in SMEs: The importance of strategic orientation and competitive structure. European Journal of Marketing, 38(9/10), 1091 - 1112.

Shipton, H., West, M. A., Dawson, J., Birdi, K., \& Patterson, M. (2006). HRM as a predictor of innovation. Human Resource Management Journal, 16, 314.

Sorensen, J. B., \& Stuart, T. E. (2000). Aging, obsolescence, and organizational innovation. Administrative Science Quarterly, 45(1), 81-95.

Subramaniam, M., \& Youndt, M. A. (2005). The influence of intellectual capital on the types of innovative capabilities. Academy of Management Journal, $43(3), 450-463$.

Swink, M. (2006). Building collaborative innovation capability. Research Technology Management, 49(2), 37-47.

Tang, H. K. (1999). An inventory of organizational innovativeness. Technovation, 19(1), 41-52.

Thamhain, H. J. (1990). Managing technologically innovative team efforts toward new product success. The Journal of Product Innovation Management, 7(1), 5-19.

Thamhain, H. J. (2003). Managing innovative R\&D teams. R\&D Management, 33, 297-311.

Thorpe, R., Holt, R., Macpherson, A., and Pittaway, L. (2005). Using knowledge within small and medium-sized firms: A systematic review of the evidence. International Journal of Management Reviews, 7(4), 257-281.

Tidd, J. (2001a). Innovation management in context: Environment, organisation and performance. International Journal of Management Reviews, 3(3), 169-183.

Tidd, J., Bessant, J., and Pavitt, K. (2001). Managing innovation: Integrating technological, market and organisational change (2nd ed.). Chichester: John Wiley \& Sons Ltd.

Tranfield, D., Denyer, D., and Smart, P. (2003). Towards a methodology for developing evidence-informed management knowledge by means of systematic review. British Journal of Management, 14, 207-222.

van der Panne, G., van Beers, C., \& Kleinknecht, A. (2003). Success and failure of innovation: A literature review. international Journal of Innovation Management, 7(3), 309-338. 
Vandermerwe, S. (1987). Diffusing new ideas in-house. The Journal of Product Innovation Management, 4(4), 256-268.

Veugelers, R., \& Cassiman, B. (1999). Make and buy in innovation strategies: Evidence from Belgian manufacturing firms. Research Policy, 28, 63-76.

Vrakking, W. J. (1990). The innovative organization. Long Range Planning, 23(2), 94-103.

Watts, T., Swann, P., \& Pandit, N. R. (1998). Virtual reality and innovation potential. Business Strategy Review, 9(3), 45-59.

Wolfe, R. (1994). Organisational innovation: Review, critique and suggested research directions. Journal of Management Studies, 31(3), 405.

Wood, A. (2003). Managing employee ideas-from where do ideas come? The Journal for Quality and Participation, 26(2), 22-28.

Woodman, R. W., Sawyer, J. E., \& Griffin, R. W. (1993). Toward a theory of organizational creativity. Academy of Management. The Academy of Management Review, 18(2), 293-322.

Yen, D. C., \& Chou, D. C. (2001). Intranets for organizational innovation. Information Management \& Computer Security, 9(2/3), 80-87.

Zhuang, L., Williamson, D., \& Carter, M. (1999). Innovate or liquidate - are all organisations convinced? A two-phased study into the innovation process. Management Decision, 37(1), 57 - 71.

Zwetsloot, G. (2001). The management of innovation by frontrunner companies in environmental management and health and safety. Environmental Management and Health, 12, 207-214. 